Vol. 45, N. 1 : pp. 47 - 51, March, 2002

ISSN 1516-8913 Printed in Brazil

BRAZILIAN ARCHIVES OF BIOLOGY AND TECHNOLOGY

AN INTERNATIONAL JOURNAL

\title{
Populational Diversity on Leaf Morphology of Maté (Ilex paraguariensis A. St.-Hil., Aquifoliaceae)
}

\author{
Geraldo Ceni Coelho ${ }^{1 *}$; Jorge Ernesto de Araujo Mariath ${ }^{2}$ and Eloir Paulo Schenkel ${ }^{\mathbf{3}}$ \\ ${ }^{I}$ Depto. de Biologia e Química, Universidade de Ijuí, Campus Linha 3 Oeste, Cx. P. 560, 98.700 - 000 Ijui-RS, \\ Brazil; ${ }^{2}$ Depto de Botânica, Universidade Federal do Rio Grande do Sul, Av. Bento Gonçalves, 9500, prédio \\ 43423, sala 206, Campus do Vale, 91.501-970 Porto Alegre-RS, Brazil; ${ }^{3}$ Faculdade de Farmácia, Universidade \\ Federal do Rio Grande do Sul, Av. Ipiranga, 2752, 90.610-000, Porto Alegre-RS, Brazil
}

\begin{abstract}
Maté (Ilex paraguariensis A. St.-Hil.) is a native plant from southern Brazil and a raw material for beverages. To research on population variability of the species, we compared leaf morphology of three populations from Mato Grosso do Sul (MS), Paraná (PR) and Santa Catarina (SC) States. Lamina measurements included area $(A)$, perimeter $(P)$, length $(l)$, maximum width $(w)$, distance between maximum width and lamina base (dw), base angle $(B \hat{A})$, biomass $(m)$, and the indexes: relative distance of maximum width $(d w / l)$, ratio length/width $(l / w)$, relative perimeter $(R P=P /(l+w)$, rectangular area index $(R A I=A /(l \times w))$ and leaf mass/area $(m / A)$. We verified differences among populations on $A \quad(M S<P R=S C), \quad l \quad(M S<P R=S C), \quad w \quad(M S<P R=S C), \quad R A I$ $(M S=P R>S C)$ and $m / A(M S>P R, M S=S C, P R=S C)$. The lowest $R A I$ of $S C$ could be explained, at least partially, by a positive correlation between $R A I$ and $B \hat{A}(r=0.6043, p<0.01)$.
\end{abstract}

Key words: Ilex paraguariensis, Aquifoliaceae, plant morphology, leaf morphology, population variability, rectangular area index

\section{INTRODUCTION}

Maté (Ilex paraguariensis A. St.-Hil., Aquifoliaceae) is a shade-tolerant tree (Floss, 1994; Coelho, 1995; Carpanezzi, 1995; Coelho \& Mariath, 1996) from the south of Brazil, Misiones, Argentine, east of Paraguay, and from some isolated populations in Uruguay (Giberti, 1995). The leaves and stems of maté are raw material for tea and beverages (chimarrão, tereré), constituting an important economic business.

Plant leaves are an important interface to the environmental factors. Some morphological characters e. g. area and thickness are strongly modified by ecological conditions. Changes on features of leaves could be a part of adaptation responses in face to these factors, for example light intensity and water supply (Groom \& Lamont, 1997).

This work was aimed at verifying the influence of different geographical origins on the morphology of maté leaves. This is a part of a research program about life history, ecology and populational variability of maté (Winge et al., 1995; Coelho \& Mariath, 1996). The leaf morphology of three different native populations from Brazil was analysed. These populations were under exploitation in such a way that the original forest was excluded and the maté plants were the

\footnotetext{
* Author for correspondence
} 
remaining trees. The management could be considered very similar for all populations, allowing the comparative study.

\section{MATERIALS AND METHODS}

Three populations of maté (Table 1) from Mato Grosso do Sul (MS), Paraná (PR), and Santa Catarina (SC) were compared. The plants were numbered in situ for further studies on genetics, physiology, morphology, ecological and chemical analysis (Table 1). We analysed a sub-sample from each population. Plants were identified by the authors and voucher specimens were deposited at ICN (Universidade Federal do Rio Grande do Sul, Porto Alegre, Brazil).Leaves without damages by herbivores and pathogens were collected in February, 1999, at a $2 \mathrm{~m}$ height along all quadrants of the trees, including only leaves from the fifth to the eighth node 7 leaves from each plant and 9 plants from each population were sampled.
Leaves digital images were obtained by a Scanner and the image analysis was accomplished by the Somnium 1.0 software (Plant Anatomy Laboratory, UFRGS, Porto Alegre-RS, Brazil).The morphological data obtained were area (A), perimeter $(\mathrm{P})$, length (1), maximum width $(\mathrm{w})$, distance between maximum width and lamina base $(\mathrm{dw})$, and the base angle (BÂ). Furthermore, we calculated the following indexes:

Relative distance maximum width, $\mathrm{O}=\mathrm{dw} / \mathrm{l}$

Length / width ratio, $\mathrm{LWR}=1 / \mathrm{w}$

Relative perimeter, $\mathrm{RP}=\mathrm{P} /(\mathrm{l}+\mathrm{w})$

Rectangular area index, $\mathrm{RAI}=\mathrm{A} /(1 x \mathrm{w})$

Additionally, the lamina biomass (m) was measured, with a semi-analytic balance Setra ELS 200s, allowing the achievement of leaf mass / area: LMA $=\mathrm{m} / \mathrm{A}$. Populations and plants were compared through a Nested Analysis of Variance for each parameter and index. The significance of correlation index between BÂ and RAI was tested by a ANOVA (Zar, 1999).

Table 1 - Plants from each population and location.

\begin{tabular}{llll}
\hline State & Plants & Locality & Co-ordinates \\
\hline MS & $05,09,15,27,42,49,253,267,268$ & Iguatemi & $23^{\circ} 40^{\prime} \mathrm{S}, 54^{\circ} 28^{\prime} \mathrm{W}$ \\
& & Tacuru & $23^{\circ} 44^{\prime} \mathrm{S}, 54^{\circ} 49^{\prime} \mathrm{W}$ \\
PR & $51,64,91,280,285,289,290,296,299$ & Pinhão & $25^{\circ} 20^{\prime} \mathrm{S}, 51^{\circ} 11^{\prime} \mathrm{W}$ \\
& & & $25^{\circ} 26^{\prime} \mathrm{S}, 51^{\circ} 31^{\prime} \mathrm{W}$ \\
SC & $105,108,129,130,143,302,303,307,308$ & Catanduvas & $27^{\circ} 03^{\prime} \mathrm{S}, 51^{\circ} 40^{\prime} \mathrm{W}$ \\
\hline
\end{tabular}

Table 2 - Average values of measurements in each population, with parameters / index range below; significant differences $(\alpha=0.05$, Nested ANOVA) are indicated by $*$, averages with different letters are statistically different after the Tukey test on each parameter/index.

\begin{tabular}{|c|c|c|c|c|c|c|c|c|}
\hline & & & populations & & & & significance & \\
\hline $\begin{array}{l}\text { parameter/ } \\
\text { index }\end{array}$ & $\mathrm{MS}$ & & PR & & $\overline{\mathrm{SC}}$ & & $\begin{array}{l}\text { among } \\
\text { populations }\end{array}$ & $\begin{array}{l}\text { among } \\
\text { plants }\end{array}$ \\
\hline $1(\mathrm{~cm})$ & $\begin{array}{r}6.37 \\
(4.91-7.59)\end{array}$ & $\mathrm{a}$ & $\begin{array}{r}7.92 \\
(6.54-10.29)\end{array}$ & $\mathrm{b}$ & $\begin{array}{r}7.83 \\
(6.41-10.89)\end{array}$ & $\mathrm{b}$ & $*$ & $*$ \\
\hline $\mathrm{w}(\mathrm{cm})$ & $\begin{array}{r}2.99 \\
(2.54-3.32)\end{array}$ & $\mathrm{a}$ & $\begin{array}{r}3.55 \\
(2.99-4.07)\end{array}$ & $b$ & $\begin{array}{r}3.66 \\
(2.89-4.86)\end{array}$ & $\mathrm{b}$ & $*$ & $*$ \\
\hline $\mathrm{A}\left(\mathrm{cm}^{2}\right)$ & $\begin{array}{r}13.17 \\
(8.56-17.09)\end{array}$ & $\mathrm{a}$ & $\begin{array}{r}19.47 \\
(15.07-26.00)\end{array}$ & $\mathrm{b}$ & $\begin{array}{r}19.41 \\
(12.39- \\
35.15)\end{array}$ & $\mathrm{b}$ & $*$ & $*$ \\
\hline $\operatorname{LMA}\left(\mathrm{mg} / \mathrm{cm}^{2}\right)$ & $\begin{array}{r}16.49 \\
(13.86- \\
20.49)\end{array}$ & $\mathrm{a}$ & $\begin{array}{r}13.96 \\
(11.38-16.10)\end{array}$ & $\mathrm{b}$ & $\begin{array}{r}14.29 \\
(10.88- \\
18.81)\end{array}$ & $a b$ & $*$ & $*$ \\
\hline $\mathrm{dw} / 1$ & $\begin{array}{r}0.611 \\
(0.554- \\
0.644)\end{array}$ & a & $\begin{array}{r}0.625 \\
(0.564-0.662)\end{array}$ & $\mathrm{a}$ & $\begin{array}{r}0.632 \\
(0.591- \\
0.660)\end{array}$ & $\mathrm{a}$ & n. s. & n. s. \\
\hline $1 / \mathrm{w}$ & $\begin{array}{r}2.08 \\
(1.62-2.63)\end{array}$ & $\mathrm{a}$ & $\begin{array}{r}2.27 \\
(2.07-2.28)\end{array}$ & $\mathrm{a}$ & $\begin{array}{r}2.15 \\
(2.05-2.25)\end{array}$ & a & n. s. & n. s. \\
\hline $\mathrm{Pe} /(1+\mathrm{w})$ & $\begin{array}{r}2.09 \\
(2.05-2.12)\end{array}$ & $\mathrm{a}$ & $\begin{array}{r}2.12 \\
(2.07-2.28)\end{array}$ & $\mathrm{a}$ & $\begin{array}{r}2.15 \\
(2.05-2.25)\end{array}$ & $\mathrm{a}$ & n. s. & n. s. \\
\hline RAI & 0.685 & $\mathrm{a}$ & 0.687 & a & 0.654 & $\mathrm{~b}$ & $*$ & n. s. \\
\hline
\end{tabular}




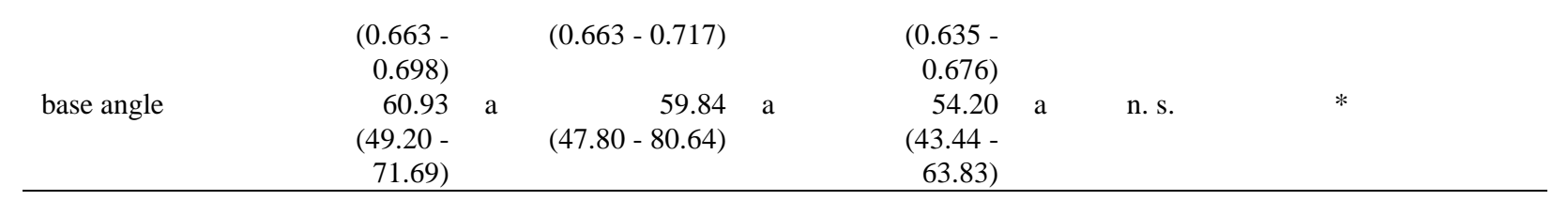

\section{RESULTS}

The average values observed to each population to the diverse parameters and indexes are showed in Table 2.

Among the indexes, differences only in RAI were observed. Santa Catarina (SC) presented a lower average value. There was no significant difference between plants inside each population, which reinforced the great concern of this parameter to distinguish the populations. The observed values (minimum, maximum, average) were in agreement with the values noticed by Mutinelli (1990), who presented a review on morphology of Ilex paraguariensis from Argentine, Paraguay and Brazil. The unique exception was the minimum value of $1 / w$ from the MS population.

To investigate the causes of the minor RAI of SC, the base angle of the lamina was also measured (Table 2), considering the hypothesis that a reduction on base angle (without change in length and width) could reduce the RAI. Of course, SC showed a minor value of base angle, in spite of no significant differences among populations (Table 2 ). The high variation among plants have possibly hindered the observation of differences among populations. On the other hand, there was a positive correlation between RAI and base angle (Figure 1). Taking into account a determination coefficient of only 0.365 , others non-determined factors should also influence this index.

Digitised leaves images were generated (Figure 2) with the average values for each population (Table 2 ), to confirm the influence of the base angle on the RAI.

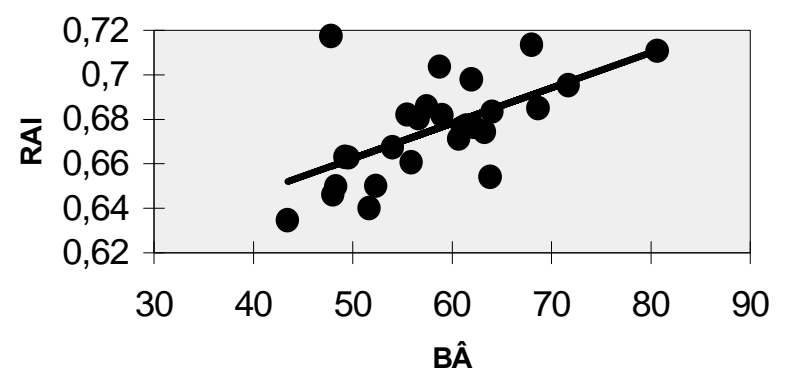

Figure 1 - Relation between RAI and the base angle in maté plants from different populations, analysed together; $\mathrm{r}^{2}=0,365, \mathrm{y}=0,5829+0,00159 \mathrm{x}, \quad p<0.01$ (ANOVA).

The obtained RAI is shown in Table 3. In this simulation, RAI of SC was $2.71 \%$ minor in relation to PR's RAI. In the original average values (Table 2), this difference was $4.83 \%$.

The inferior reduction verified in the simulation was, therefore, coherent with the correlation between RAI and base angle (Figure 1), demonstrating again the existence of other factors aside the base angle to reduce the RAI of the SC population.

It was possible to observe, additionally, a low proportion of base area (or increase of apical area) in the SC's virtual leaf, while PR and MS leaves have identical base areas (Table 3). The data emphasise the similarity of leaf morphology between PR and MS, in spite of differences in linear measurements (length, width) and area.

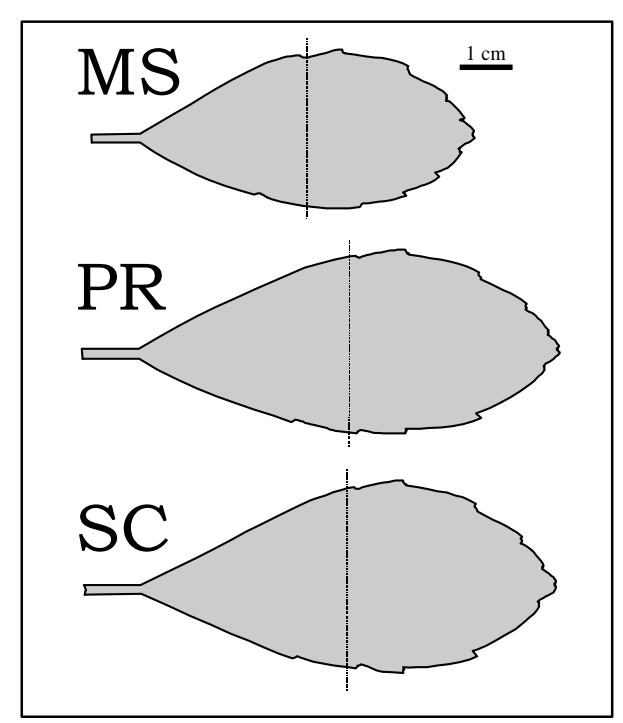

Figure 2 - Virtual leaves generated from the average values of length, width, distance of maximum width to the base, and base angle of each population. The dashed line divide the lamina at half length. 
Table 3 - Area, RAI and proportion of the half base area (\%hba), obtained through simulation of virtual leaves with the average values $(1, w, d w, B \hat{A})$ of each population.

\begin{tabular}{lll|lll}
\hline & \multicolumn{3}{l|}{ Original values } & \multicolumn{3}{c}{ calculated values } \\
\hline & 1 & W & A & RAI & $\%$ hba \\
MS & 6,37 & 2,99 & 11,71 & 0,616 & 43,19 \\
PR & 7,92 & 3,55 & 17,06 & 0,607 & 43,19 \\
SC & 7,83 & 3,66 & 16,92 & 0,591 & 40,79 \\
\hline
\end{tabular}

\section{DISCUSSION}

Generally, for plants of the same species, high values of LMA are related to high intensity of light (Osunkoya \& Ash, 1991; Mulkey et al., 1993; Kitajima, 1994; Muraoka et al., 1997). This response is related to increased thickness of the leaf tissues (Hanson, 1917), especially the palisade parenchyma (Fretz \& Dunham, 1972). LMA increased linearly with increasing relative irradiance and therefore it may be considered a species-specific estimate of long-term light conditions (Niinemets, 1997). Diminished water supply can contribute to the reduction of LMA in some cases (Groom \& Lamont, 1997), while in others no difference was observed (Mulkey et al., 1993).

The area is negatively correlated with the light intensity, when comparing plants of the same population or leaves from the same tree (Crawley, 1997; Kozlowsky \& Pallardy, 1997). Considering similar conditions of management for the three populations studied in this paper, the small area and high LMA of leaves from Mato Grosso do Sul could point out a particular climatic condition.

The applied indexes are related to the leaves morphology, for example $\mathrm{dw} / \mathrm{l}$ is a measurement of how much a leaf is obovate (diverging from the elliptic type). Comparing plants and populations, we observed differences only in RAI, suggesting that $I$. paraguariensis could change its dimensions (width, length, area) with superficial (if any) form modifications. Form parameters could exhibit less genetic plasticity (Smith \& Hake, 1994), emphasising the importance of the different value of RAI to SC population. This low RAI is partially caused by the low average value of BÂ. Decrease of $\mathrm{BA}$ can increase the proportion of area on the lamina apical half, amplifying the exposure to light. This morphological change could be a response to a more shaded environment.
Oppositely, a increase of BÂ could be a adaptation to environments with a high light intensity and/or edaphic limitations to the photosynthesis through an increased auto-shading.

It is important to highlight the populational differences observed here to I. paraguariensis, considering the high intrapopulational diversity of this species (Winge et al., 1995). New experiments are being carrying out to measure the leaves plasticity of plants from the same population, and how they could change its morphology when submitted to variations on the environmental factors.

\section{ACKNOWLEDGEMENTS}

The authors are grateful to Dra. Helga Winge (UFRGS) and Luis Carlos Tarasconi (FEPAGRO), for scientific and logistical assistance, and to Renato Dedecek (EMBRAPA, Colombo-PR), Mate Santo Antônio Ltda. (Ponta Porã-MS), Fazenda Mate Amargo (Iguatemi-MS), Schier Ltda. (Guarapuava-PR), Bitumirim (Ivaí-PR), Regina Ltda. (Catanduvas-SC) and Ximango (Ilópolis-RS) for the support during collections. Thanks are also due to Ricardo Pires dos Santos for assistance with the Somnium 1.0 software, and to Mára L. Tissot (UNIJUÍ) for the methods suggestions. To UNIJUÍ for fellowship (G. C. Coelho) and to FAPERGS (97/0505-7, 98/0439-0) for financial support.

\section{RESUMO}

Erva-mate (Ilex paraguariensis A. St.-Hil.) é uma planta nativa do Brasil, e matéria-prima para bebidas e chás. Analisou-se sua variabilidade populacional, comparando-se a morfologia das folhas de 3 diferentes populações do Mato Grosso do Sul (MS), Paraná (PR) e Santa Catarina (SC). Avaliou-se área $(\mathrm{A})$, perímetro $(\mathrm{P})$, comprimento (c), largura máxima (l) e biomassa (m), distância da largura máxima até a base (dl), ângulo basal da lâmina (Âb), e os índices: distância relativa da largura média $(\mathrm{DLM}=\mathrm{dl} / \mathrm{l})$, razão comprimento/largura $(\mathrm{RCL}=\mathrm{c} / 1)$, perímetro relativo $(\mathrm{PR}=(\mathrm{c}+1) / \mathrm{Pe})$, índice de área retangular $(\mathrm{IAR}=\mathrm{A} /(\mathrm{c} x \mathrm{l}))$ e massa específica $(\mathrm{m} / \mathrm{A})$. Há diferenças em A $(\mathrm{MS}<\mathrm{PR}=\mathrm{SC})$, c $(\mathrm{MS}<\mathrm{PR}=\mathrm{SC}), \quad 1 \quad(\mathrm{MS}<\mathrm{PR}=\mathrm{SC}), \quad \mathrm{IAR}$ 
$(\mathrm{MS}=\mathrm{PR}>\mathrm{SC})$ e $\mathrm{m} / \mathrm{A}(\mathrm{MS}>\mathrm{PR}, \mathrm{PR}=\mathrm{SC}, \mathrm{MS}=\mathrm{SC})$. $\mathrm{O}$ IAR menor de SC pôde ser explicado, pelo menos em parte, pela correlação entre IAR e Âb $(r=0,6043, p<0,01)$.

\section{REFERENCES}

Carpanezzi, A. A. (1995), Cultura do mate no Brasil: conflitos e lacunas. In: Erva-mate - Biologia e Cultura no Cone Sul, eds. H. Winge, A. G. Ferreira, J. E. A. Mariath, L. C. Tarasconi. Editora da Universidade Federal do Rio Grande do Sul, Porto Alegre, 43-46.

Coelho, G. C. (1995), Anatomia foliar e morfologia de inflorescências das espécies sul-rio-grandenses de Ilex L. (Aquifoliaceae), Master dissertation, pósgraduação em Botânica, UFRGS, Porto Alegre, Brazil.

Coelho, G. C. and Mariath, J. E. A. (1996), Inflorescences morphology of Ilex L. (Aquifoliaceae) species from Rio Grande do Sul, Brazil. Feddes Repertorium (Berlin), 107, 19-30.

Crawley, M. J. (1997), Life history and environment. In: Plant Ecology, ed. M. J. Crawley. $2^{\text {th }}$ ed., Blackwell Science Ltd., Cambridge, UK.

Floss, P. A. (1994), Variações genéticas entre populações naturais de Ilex paraguariensis St. Hil. (erva-mate) avaliadas em Chapecó, SC e Três Barras, SC. Master Dissertation, ESALQ/USP, Piracicaba, Brazil.

Fretz, T. A. and Dunham, C. W. (1972), Influence of 3 levels of light-intensity on leaf structure, area and color difference in american holly, Ilex opaca AIT. cv Miss Helen. Phyton - International Journal of Experimental Botany, 30, 135-139.

Groom, P. K. and Lamont, B. B. (1997), Xerophytic implications of increased sclerophylly: interactions with water and light in Hakea psilorrhyncha seedlings. New Phytologist, 136, 231-237.

Giberti, G. C. (1995), Aspectos oscuros de la cronologia de Ilex paraguariensis St. Hil. In: Ervamate - Biologia e Cultura no Cone Sul. eds. H. Winge, A. G. Ferreira, J. E. A. Mariath, L. C. Tarasconi. Editora da Universidade Federal do Rio Grande do Sul, Porto Alegre, pp. 289-302.

Hanson, H. C. (1917), Leaf strutucture as related to environment. American Journal of Botany, 4, 533560 .
Kitajima, K. (1994), Relative importance of photosynthetic traits and allocation patterns as correlates of seedling shade tolerance of 13 tropical trees. Oecologia, 98, 419-428.

Kozlowsky, T. T. and Pallardy, S. G. (1997), Physiology of woody plants. $2^{\text {th }}$ ed., Academic Press, San Diego, E.U.A.

Mulkey, S. S; Wright, S. J. and Smith, A. P. (1993), Comparative physiology and demography of three neotropical forest shrubs: alternative shade-adaptive character syndromes. Oecologia, 96, 526-536.

Muraoka, H.; Tang, Y.; Koizumi, H. and Washitani, I. (1997), Combined effects of light and water availability on photosynthesis and growth of Arisaema heterophyllum in the forest understory and an open site. Oecologia, 112, 26-34.

Mutinelli, A. (1990), Biometria foliar de la yerba mate (Ilex paraguariensis St. Hil. var paraguariensis), Nota Técnica (INTA - Cerro Azul), 43, 1-16.

Niinemets, U. (1997), Role of foliar nitrogen in light harvesting and shade tolerance of four temperate deciduous woody species. Functional Ecology, 11, 518-531.

Osunkoya, O. O. and Ash, J. E. (1991), Acclimation to a change in light regime in seedlings of 6 australian rain-forest tree species. Australian Journal of Botany, 39, 591-605.

Smith, L. G. and Hake, S. (1994), Molecular approaches to leaf development: Knotted and beyond. Canadian Journal of Botany, 72, 617-625.

Winge, H.; Wollheim, C.; Cavalli-Molina, S.; Assmann, E. M.; Bassani, K. L. L.; Amaral, M. B.; Coelho, G. C.; Freitas-Sacchet, A. M. O.; Butzke, A.; Valduga, A. T. and Mariath, J. E. A. (1995), Variabilidade genética em populações nativas de Erva-mate e a implantação de bancos de germoplasma, eds. H. Winge, A. G. Ferreira, J. E. A. Mariath, L. C. Tarasconi. Editora da Universidade Federal do Rio Grande do Sul, Porto Alegre, 323346.

Zar, J. H. (1999), Biostatistical Analysis. $4^{\text {th }}$ ed., Prentice Hall, New Jersey, E.U.A.

Received: April 10, 2000;

Revised: July 18, 2000

Accepted: March 06, 2001. 